\title{
THE PERCEPTION ON ULUM AL-QURAN COURSE: A COMPARATIVE STUDY BETWEEN RESEARCH UNIVERSITIES
}

\author{
Mohamed Akhiruddin Ibrahim ${ }^{1 \star}$ Zulkifli Haji Mohd Yusoff ${ }^{2}$, Adnan Mohamed Yusoff ${ }^{3}$ \\ Mohammad Hikmat Shaker ${ }^{4}$, Shahirah Sulaiman ${ }^{5}$, Ahmad Shahir Mohd Shah ${ }^{6}$ and \\ Nur Sakina Razli ${ }^{6}$ \\ ${ }^{1}$ Dr, Senior Lecturer, Faculty of Quranic and Sunnah Studies, Universiti Sains Islam Malaysia, \\ MALAYSIA, akhiruddin@usim.edu.my \\ ${ }^{2}$ Professor, Dr, Centre of Quranic Studies, University of Malaya, MALAYSIA \\ ${ }^{3} \mathrm{Dr}$, Assoc. Prof., Faculty of Quranic and Sunnah Studies, Universiti Sains Islam Malaysia, \\ MALAYSIA \\ ${ }^{4} \mathrm{Dr}$, Lecturer, Islamic College of Melbourne, AUSTRALIA \\ ${ }^{5}$ Language Teacher, Tamhidi Centre, Universiti Sains Islam Malaysia, MALAYSIA \\ ${ }^{6}$ Student, Faculty of Quranic and Sunnah Studies, Universiti Sains Islam Malaysia, MALAYSIA \\ ${ }^{*}$ Corresponding author
}

\begin{abstract}
The study of Ulum Al-Quran explores the unique of style and arrangement of the Al-Quran and the various ways in which people have tried to understand its meanings comprehensively. For Islamic studies amongst public research universities, they will need to study this course in order to complete their studies' credit hour to fulfil the requirement of their respective faculty. Hence, this study focused on students' perception of Ulum Al-Quran course in higher education at two research universities namely; National University of Malaysia (UKM) and University of Malaya (UM). The aims of this research are to know the perception of students about Ulum Al-Quran course, the acceptance of Ulum Al-Quran course outline and Ulum Al-Quran reference book or syllabus. The results from the respondents' feedbacks, is expected to assist the public research universities and the lecturers; especially the department of Islamic Studies, to assess the strengths and weaknesses of what has been done in implementing the lesson towards better improvement in Ulum AlQuran studies.
\end{abstract}

Keywords: University, Ulum Al-Quran, Islamic studies, research universities, perception

\section{INTRODUCTION}

Studies related to the knowledge of Quran are one of the areas that are essential to enable a person to understand and explain or interpret what occurs in the Quran comprehensively. Quran contains the revelations of Allah, the Creator and Compeller of the Universe, to His mankind. It is the message from Allah to man as; therefore, Quran is the utmost importance to us to embrace it. In order to properly grasp a 
message, one needs first of all to understand its contents exactly, and for this purpose one must study Quran accordingly. In fact, some people do spend their whole lives studying Quran by reciting, reading and reflecting upon it and, as they grow and develop, both physically and spiritually, they discover for themselves new meanings and implications (Von Denffer \& Souaiaia, 2004).

Although the reliable and authentic sources or references knowledge of Quran were since the 3rd century, in fact it has started indirectly since the time of Prophet Muhammad (PBUH). However, during that time, the knowledge of Quran is still not much organized. There are many definitions of terms. In addition, some scholars claimed that Ulum Al-Quran is the knowledge of Quran; either in terms the way of reciting it, the history of the chapters, compilation, writing, interpretation, i'jaz, the reasons for the sentence, i'rab and gharib Al-Quran.

According to Al-Zarqani (1983), Ulum is the study of the Quran itself, in terms of the chapters, the way of reciting it, interpretation, i'jaz, nasikh and mansukh and all things related to the Quran. Meanwhile, Al-Suyuti (1999) said, Ulum Al-Quran is a field that discusses Quran in terms of manners, interpretation, enunciation and others that associated with it. It can be concluded that, the meaning of Ulum Al-Quran means understanding the actual respect of the Quran which includes asbab al-nuzul, ayah makkiyyah and madaniyyah, nasikh and mansukh, the way of reciting it, collecting, writing and various aspects that are relating to Quran. Furthermore, the content of is mainly on the knowledge that will lead people to know Allah and our beloved Prophet Muhammad (PBUH) (Islamic Religious Council of Singapore, p. 7).

Quran is the greatest mu'jizat of Prophet Muhammad (PBUH). Although Quran is in Arabic, it does not mean that all Arab people who are proficient in Arabic can understand Quran in details. Quran is a holy book that has high literary value. The language is rich and has meaningful words. It could not be compared even to the greatest Arabic literature. Ulum Al-Quran is a translation of what scholars considered as, indispensable linguistic and stylistic tools for comprehending the meanings of Quran (Al-Suyuti, 1999). In order to understand the teachings of Islam perfectly, it takes an understanding of the Quran and practices it in everyday life consistently. On that note, Ulum Al-Quran is imperative as the gateway to understand Quran accordingly.

\section{LITERATURE REVIEW}

A study on Ulum Al-Quran is important to allow a person to understand and explain or interpret what occur in the Quran by itself. There are numbers of literatures and book discusses on this area. For instance, in Rosmawati (1997), she stated that Ulum Al-Quran is the method of collecting Quran as well as composition of the verse in the Quran. Meanwhile, in Zatil's writing (2010), she discovered that Ulum Al-Quran is used as focused on Quran subject in j-Qaf (Jawi, Quran, Arabic Language and Prayers) programme among students. The main objective of the Ulum-Al-Quran in the j-Qaf programme is to identify the knowledge of Quran's level among students and how effective the syllabus used by j-Qaf's teacher within learning and teaching in classes as well as how does it helps to recover weak students in Quran; as to know the problems faced by the students during Quran learning's period.

Meanwhile, in Ushama's book (2013), Ulum Al-Quran is to provide a critical and meaningful introduction to the methodologies of the Quran exegesis (Manhaj Al-Tafsir) for the university students in general and researchers in particular. This is pioneering study and is necessitated by the absence of an objective and analytical work on methodologies of the Quran exegesis of both classical and contemporary periods in English language. The book deals in comprehensive manner with different kinds, principles, characteristics and methodologies of the Quran exegesis.

As for Von Deffer, et. al's work (2004), Ulum Al-Quran is to explain about the proper approach to the Quran that can be described in three stages. Firstly, receive the message of the Quran by hearing or reciting it. Secondly, understand the Quran by reflecting upon it and studying its meaning. Thirdly, apply the message of the Quran by ordering your personal life as well as the life of society according to its message. Ulum AlQuran is used for the understanding the message of the Quran, by understanding its setting and circumstances. It is to help towards better understanding of the Quran message by providing information on its setting, framework and circumstances.

In Qattan's book (2000), explains that Ulum Al-Quran discusses the detail about Quran's revelation and the role of Gabriel in the delivering the revelation, scientific evidence that can be used as an argument to the existence of a revelation, reason or background to descend Quran verses, verses of Makkiyah and Madaniyyah and also about how Quran is collected and maintained so that it still exists with its original contents as conveyed by the prophet Muhammad (PBUH) to his friends.

By these sources, it denotes that Quran is the absolute significance for humankind to embrace it. In order to 
properly grasp Quran's message, one needs to understand and reflect upon it both cognitively and spiritually, of its meanings and implications. On that note, this paper intends to seek of the perceptions on Ulum Al-Quran courses that have been taught and introduced to students in the two research universities.

\section{RESEARCH METHODOLOGIES}

This paper was conducted in a mixed-method approach as in quantitative and qualitative study whereby questionnaire and data analyses were used.

\section{Data Collection Method}

The researcher's main means of data collection was by the questionnaires answered by the respondents and Historical Method. Historical method is the data that were collected and analysed by looking at historical facts and root of information with the aim of answering some of the research question. The researcher used this method to compare the perception amongst the student at different universities using surveys and questionnaires (Russ-Eft \& Preskill, 2001).

\section{Data Analysis Method}

Later, the researcher processed the data and facts by using the methods outlined as below:

a) Inductive Method

This method is a tool to analyse data by reasoning. This process demands the acquisition of evidence leading for small details to general facts and patterns.

\section{b) Deductive Method}

Deduction is a method of reasoning that uses facts to prove specific matters.

c) Comparative Method

This method commonly used to summarize or conclude two or more theories by comparing them during the analysis. The complete data and facts need to be collected before any comparison can be done.

\section{FINDINGS AND RESULTS}

This research was held at two public research universities which are; National University of Malaysia (UKM) and University of Malaya (UM). Since 2004, all public universities were placed under the jurisdiction of the newly organized Ministry of Higher Education (Hussein, 2014). The researcher has limited the study to present the student's perception about learning Ulum Al-Quran and anything that related to Ulum Al-Quran in these universities. The students who involved were from Islamic Studies students as they study the content of Quran and Sunnah respectively (Mohd Aderi \& Ahmad Yunus, 2012, Mohd Aderi, 2013).

The results of the findings were divided into five sections; $A, B, C, D$ and $E$. Section $A$ is to obtain on the sample background. Section B is on the students' perceptions of Ulum Al-Quran course. Section C is on the students' perceptions of the Ulum Al-Quran's course outline. Section D comprised the students' perception on reference books or syllabus used in class. Finally, Section E is the students' prospects on Ulum Al-Quran course. The total number of respondents was 100 people. A total of $50(50 \%)$ respondents were students from UKM and 50 students (50\%) were from UM.

\subsection{Background of the Respondents}

It is noticed that almost more than half of the respondents were from government and government-aided National Religious Secondary Schools; that is 40 of UKM and 38 of UM respondents. These types of schools stress the important of Islamic studies (Abdul Hafiz et. al, 2012). On the feedback of the Ulum Al-Quran course's interest amongst students; 25 respondent from UKM responded that they have a very high interest on Ulum Al-Quran course, while 20 respondent from UM responded the same.

It is discovered that there are the same number of UKM and UM's respondents that got $A$ for their achievement in Ulum Al-Quran courses in their lesson, with 28 respondents. Furthermore, 32 of UKM and 31 of UM respondents responded that they have obtained Ulum Al-Quran exposure and knowledge since their secondary school.

\subsection{Students' Perceptions on Ulum Al-Quran Course}

Surprisingly, it is found that there were 21 of UKM and only 13 of UM respondents strongly agree that the course content is easy to understand. While, 9 of UKM and 14 of UM respondents were not sure that the content is easy to understand. There are 18 of UKM and 21 of UM respondents agree that they gained lots 
of knowledge when they learn the course. Besides that, there are 21 of UKM and 28 of UM respondents agree that this course helped them to relate the course content with the current issues; as 22 of UKM an UM's respondent as well responded that this course will help them understand and describe the topics.

\subsection{Students' Perceptions on Ulum Al-Quran Course Outline}

This study found out that 22 of UKM and 16 of UM respondents strongly agree that the syllabus in Ulum AlQuran course outline required is suitable with their studies. In addition, 25 of UKM 13 of UM respondents strongly agree that the content of the Ulum Al-Quran's course outline can be understood as prescribed by the faculty. Last but not least, 18 of UKM and 30 of UM respondents agree that the course set by the university faculties are organized and systematic. While, 15 of UKM and 10 of UM respondents are not sure that the course set by the university faculties are organized and systematic

\subsection{Students' Perceptions on Ulum Al-Quran Reference Books or Syllabus Used In Class}

There were the same number of UKM and UM respondents, with 28 students agree that they have gained a lot of knowledge by using the reference books or syllabus used in class. However, 15 of UKM respondents and only 6 of UM respondents strongly agree that the reference book or syllabus used is relevant with the important points learnt. Unpredictably, only 7 of UKM and only 3 of UM respondents strongly agree that they found a reference book or syllabus that has clear explanation and no need to refer to other reference books.

\subsection{Students' Prospects on Ulum Al-Quran Course}

There were 25 of UKM and 23 of UM respondents strongly agree that they believe this course provides an understanding of the knowledge that covers all the basic knowledge about the Quran. While, 20 of UKM and 23 of UM respondents agree that by studying this course, it can help them to use it to contribute to society. In addition, 16 of UKM and 23 of UM respondents agree that this course can help to produce graduates who are skilled in the knowledge of Islam. Nevertheless, 16 of UKM and 26 of UM respondents agree that this course can add mastery of vocabulary and terms which are related with the knowledge of Ulum Al-Quran. Last but not least, 36 of UKM and 33 of UM respondents strongly agree that this course should be continued in the future.

From the findings, it is discovered that the respondents have good perception on Ulum Al-Quran course. It is reflected that the more than half of the students have the exposure and knowledge since they were in secondary schools. Nonetheless, at the university level, they learn Ulum Al-Quran into details; as they agree on the course outline and the syllabus book used in class. Also, most of the respondents responded that this course can produce more intellectual students in the future as by this knowledge, it can help them to use it to contribute to the society. Hence, it depicted that the respondents responded that Ulum Al-Quran course should be continued in the future.

\section{CONCLUSION}

As a conclusion, the results from the respondents' feedbacks, is expected to assist these public research universities and the academicians involved; especially the department of Islamic Studies, to assess the lesson towards better improvement in Ulum Al-Quran studies. Hence, some recommendations are proposed as follows. It is proposed that the course outline should be more details and more systematic in the future, as from the findings, students said that they prefer more details as well as more topics in learning this course. In addition, the assessment for students needs to be developed and improved, as some of them perceived as if they are not being evaluated accordingly. Besides that, the books used in class should be prepared in bilingual language, as not all of the students are well-skilled in Arabic or English language. Linguistic barriers to learn in regular classrooms could make these students are at risk of poor education outcomes (Aimee, 2015). Finally, the use of the premier book or source in teaching them is needed. It is requested that the books used in class should be the ones that are easy for students to refer to in understanding Ulum Al-Quran course accordingly, as example, the universities should promote the use of kitab turath during the studies. It is hoped that from the proposed ideas and findings discovered amongst the respondents in this study, it could be a guideline for Ulum Al-Quran course in any other universities to be well-tailored respectively and could be a reference for other programmes as well.

\section{ACKNOWLEDGEMENT}

The researchers would like to acknowledge Centre of Quranic Studies, University of Malaya (UM) for the 
management and Research Management Centre, Universiti Sains Islam Malaysia (USIM) for the financial support as this research was a part of its Grant (PPP/USG-0115/FPQS/30/11415).

\section{REFERENCE LIST}

Abdul Hafiz Mat Tuah, Zakaria Stapa and Ahmad Munawar. (2012). Memperkasakan Jati Diri Melayu-Muslim Menerusi Pendidikan Islam Dalam Pengajaran Akhlak. Jurnal Hadhari Special Edition (2012) 23-35.

Aimee Chin. (2015). Impact of Bilingual Education on Student Achievement. IZA World of Labor 2015: 131doi: 10.15185/izawol.131. Aimee Chin. March 2015. wol.iza.org

Al-Suyuti, J. (1999). Al-Itqan fi Ulum al-Qur'an. Cairo: Dar Al Kitab Al Arabiy.

Al-Zarqani, M. A. A. A. (1983) Manahil al-Irfan fi Ulum al-Al-Qur'an Cairo: Dar al-Fikr.

Hussein Ahmad. (2014). An Overview of the Malaysian Higher Education Issues and Challenges. Malaysian Online Journal Of Educational Management (Mojem), January 2014, Volume 2, Issue 1, 10 - 19 E-Issn No: $2289-4489$.

Majlis Ugama Islam Singapura (Islamic Religious Council of Singapore), Reflection On The Life Of Prophet Muhammad s.a.w, (http://www.muis.gov.sg/officeofthemufti/documents/Maulidur\%20Rasul\%20Booklet.pdf)

Mohd Aderi Che Noh and Ahmad Yunus Kasim (2012). Teaching of Islamic Doctrine and Beliefs in School Subject Content Knowledge and Pedagogical Considerations. International Journal of Humanities and Social Science Vol. 2 No. 11; June 2012.

Mohd Aderi Che Noh, Amjad Hussein, Othman Ghani and Asmawati Suhid. (2013). The Study of Al-Quranic Teaching and Learning: A Review in Malaysia and United Kingdom. Middle-East Journal of Scientific Research 15 (10): 1338-1344, 2013 ISSN 1990-9233 @ IDOSI Publications, 2013 DOI: 10.5829/idosi.mejsr.2013.15.10.11509.

Qattan, M.K (2000). Mabahith fi Ulum Al-Quran. Riyadh: Maktabah Al-Ma'arif li Al-Nahsr wa Al-Tawzi'.

Rosmawati Ali @ Mat Zin. (1997). Pengantar Ulum Al-Quran. Kuala Lumpur: Pustaka Salam Sdn. Bhd.

Russ-Eft, D., \& Preskill, H. (2001). Evaluation in Organizations. New York: Basic Books.

Thameem Ushama. (2013). History and Sciences of the Qur'an. Kuala Lumpur. IIUM Press.

Von Denffer, A, \& Souaiaia, A.E. (Ed.) (2004). Introduction to the Qur'an. USA: SIME Journal (http://majalla.org).

Zatil Amani Yahaya. (2010). The Study Of Syllabus And It's Effectiveness Of AI-Qur'an Subject Under J-Qaf Programme : A Case Study At Sekolah Sultan Ahasma, Alor Star. Nilai : Universiti Sains Islam Malaysia. 